Article

\title{
Evolving Spatial Data Infrastructures and the Role of Adaptive Governance
}

\author{
Jaap-Willem Sjoukema ${ }^{1, *}$, Arnold Bregt ${ }^{1}$ and Joep Crompvoets ${ }^{2}$ \\ 1 Laboratory of Geo-Information Science and Remote Sensing, Wageningen University \& Research, \\ Droevendaalsesteeg 3, 6708 PB Wageningen, The Netherlands; arnold.bregt@wur.nl \\ 2 Public Governance Institute, KU Leuven-University of Leuven, Parkstraat 45, 3000 Leuven, Belgium; \\ joep.crompvoets@kuleuven.be \\ * Correspondence: jaap-willem.sjoukema@wur.nl; Tel.: +31-317-481699
}

Received: 9 June 2017; Accepted: 10 August 2017; Published: 16 August 2017

\begin{abstract}
Spatial data infrastructures (SDIs) are becoming more mature worldwide. However, despite this growing maturity, longitudinal research on the governance of SDIs is rare. The current research examines the governance history of two SDIs in The Netherlands and Flanders (Belgium). Both represent decades-long undertakings to create a large-scale base map. During these processes, SDI governance changed, often quite radically. We analyse written accounts from geo-information industry magazines to determine if the SDI governance of these two base maps can be considered adaptive. We conclude that SDI governance was adaptive, as it changed considerably during the evolution of the two SDIs. However, we also find that most governance models did not hold up very long, as they were either not meeting their goals, were not satisfying all stakeholders or were not in alignment with new visions and ideas. In recent years, the policy instruments governing these base maps became increasingly diverse. In particular, more hierarchical instruments were introduced. Indeed, governance scholars increasingly agree that governance can better respond to changes when a broader mix of policy instruments is applied. Alas, this does not make SDI governance any less complex.
\end{abstract}

Keywords: spatial data infrastructure (SDI); governance; SDI development; self-organisation; complex adaptive systems; longitudinal analysis; large-scale base map; The Netherlands; Flanders

\section{Introduction}

\subsection{SDIs}

Spatial data infrastructures (SDIs) are becoming more mature worldwide. Their growing importance, increased connectivity and the greater participation of different public and private stakeholders have made appropriate governance essential for effective SDI development and management [1]. This is a challenge, however, due to the complex, multi-stakeholder, multi-level, technical and open nature of SDIs. As SDIs play an increasing role in society, more insight is needed into SDI governance.

In The Netherlands, Belgium and elsewhere, the governance of SDIs now often appears to be a matter of trial and error [2]. Hardly any evidence-based research exists on the effect of potential governance interventions, such as open data policy, changes in funding and coordination structures and participation of the private sector, on SDI effectiveness and efficiency. Formerly weak SDI components, such as standards, technology and data, have significantly improved over the years $[3,4]$. SDI governance might well be the "weakest link" in SDIs today.

A challenge in researching the relation between governance and SDIs is that ideas about both governance and SDIs are not stationary but change over time, place, culture and even discipline. 
This becomes clear in efforts to define these subjects, as there is a multitude of governance $[5,6]$ and SDI definitions $[7,8]$. How we think of governance or SDIs today could be very different from how we view these subjects in the future. This makes planning for future-proof SDI governance a challenge.

Though academia has no agreed governance definition [5,6], we use a holistic meaning in this research. We do not distinguish between 'hard government' and 'soft governance' [9]. Rather, we view all processes and structures for steering and managing SDIs as part of SDI governance [10]. These processes and structures can be governmentally or non-governmentally driven and can emerge from authoritarian [11], bottom-up or self-organising initiatives [12].

Kooiman [13] defines governance as follows:

Governing can be considered as the totality of interactions, in which public as well as private actors participate ... ; attending to the institutions as contexts for these governing interactions; and establishing a normative foundation for all those activities. Governance can be seen as the totality of theoretical conceptions on governing. (p. 4)

From this definition, we can distinguish three vital governance ingredients: 'actors' (public and private); 'institutions' (providing context and a foundation) and 'interactions'. In our holistic approach, these actors can be anyone. Institutions can be formal, such as laws and policies, or informal, such as culture, values and beliefs. Interactions can both be deliberate, such as hierarchical steering mechanisms or coincidental. Governance as a totality is more than the sum of these parts.

In this respect, SDIs resemble governance. Rajabifard et al. [14] define SDIs as made up of five components: 'people', 'policy', 'standards', 'data' and 'access network' (or 'technology'). As the sum of these interacting parts, the SDI itself is bigger than just the parts alone. This is also one of the features of complex adaptive systems [15]. Each SDI component, the interactions between them, as well as the SDI itself ('the sum of the parts') are in need of governance. It is therefore unsurprising that SDI governance is an incredibly complex subject that puzzles academics and practitioners alike. The current research, therefore, focuses on the evolutionary trajectory of SDI governance in the past, in the expectation that this might provide guidance for the future.

\subsection{Global Governance Trends and the Evolution of SDIs}

The concepts of governance and SDIs are continuously on the move, which only adds to their complexity. Within the governance domain, Verhoest et al. [16] observe 'an action-reaction pattern in which the solution to a problem turns into a problem itself' (p. 330). New solutions are proposed to deal with unintentionally created problems, and so a continuous pattern of improvement emerges. The same action-reaction pattern can be observed within the SDI domain.

Grus et al. [15] argue that SDIs can be seen as 'complex adaptive systems'. Adaptability, in fact, is considered a foremost SDI feature: 'A high degree of adaptability guarantees that an SDI can continuously develop by adjusting its structure, behaviour and goals to changing external circumstances' [15] (p. 457). Key features of complex adaptive systems are their unpredictability and self-organisation, which are influenced by external factors due to their openness and internal factors like their history (path-dependency).

Interestingly, governance developments appear to have partly shaped the preconditions for the development of SDIs. From the late 1970s, governance entered a transition phase from the 'golden age of planning', in which science and experts determined rationally and hierarchically the way to move forward, into a governance paradigm now widely known as 'New Public Management' (NPM). NPM stresses running governments like a business in order to save on costs and improve efficiency and effectiveness. Implementation of NPM strategies has varied widely, but NPM trends were certainly recognisable in the 1980s and 1990s in many western countries [6]. Hood [17] identifies several dimensions of change introduced by NPM, such as disaggregation and specialisation of public organisations, more competition, use of corporate management practices and a focus on measurable outputs and performance. 
The US executive order issued in 1994 by then-president Bill Clinton for a 'coordinated National Spatial Data Infrastructure' [18] (p. 1) marks for many academics and practitioners the official launching point for SDIs (e.g., [14,19]). The goal of the broader 'National Performance Review' policy in which it was embedded was 'a government that works better and costs less' [20]. This focus on performance and efficiency suggests that the order was inspired by NPM ideals.

Although the foundation of the US national spatial data infrastructure (NSDI) seems to rest on an NPM basis, the goal of the NSDI was actually to counterbalance NPM symptoms. As NPM advocated disaggregation of large bureaucracies into small specialised and competitive organisations (also known as 'agencification'), it led inevitably to fragmentation of governmental information [16]. Therefore, the US NSDI initiative sought to create cross-agency coordination, 'to avoid wasteful duplication of effort and promote effective and economical management of resources by Federal, State, local, and tribal governments' $[18,20]$.

Rajabifard et al. [21] observe a change in focus in SDI development around the start of 2000, which they call 'the second generation of National SDI initiatives' (p. 103). An important aspect of this SDI generation is a shift in emphasis from data integration to data dissemination by creating a link between data and data users. By making people an important component of an SDI, the value of the SDI increases. This realisation by SDI practitioners is an important aspect of what Rajabifard et al. [14] identify as a move away from product-based SDIs to process-based SDIs. Reasons for implementing an SDI changed from resource savings and increased productivity to the more holistic socio-cultural ideal of an SDI serving the interests of society as a whole [21,22].

Probably not coincidentally, ideas about governance also changed around the 2000s. While there seems no leading governance strategy such as NPM anymore, there is a general consensus that most western countries have moved away from a market perspective towards a network perspective on governance [6]. Indeed, in trying to achieve cross-agency coordination, it became apparent that the state is not unitary, but plural, and that not competition, but networks and relations are important for coordination. These insights can be seen as the core elements of New Public Governance (NPG), which is cautiously identified as NPM's successor [23]. While the NPG term itself is not embraced by all academics, the importance of network type mechanisms for coordination, next to market type mechanisms and hierarchy type mechanisms, is generally accepted [16].

In the 2000s, 'trust' and 'transparency' also became important notions within many public administrations, leading to the 'open government' concept. Freedom of information is here deemed important for increasing accountability, trust and public participation, which are seen as lubricants of the democratic process [6,24].

The open government concept is clearly visible within the SDI domain: concepts such as 'open standards', 'open source software' and 'open data' were already coined, but now became advocated by many governments (e.g., the European Union [25] and UK [26]). Open spatial data has resulted in growth in usage of spatial datasets [27,28], but also put pressure on data financing models [29].

The changing governance paradigms seem clearly interrelated with the evolution of SDIs. However, it would be inappropriate to think of these governance paradigms as the only agenda-setting factor. Of course, the emergence of information and communication technology (ICT) was particularly determinative in SDI evolution. Many scholars $[14,19,30,31]$ note a technology push in SDI development. Without technology, an SDI would not be feasible. Even governance paradigms such as 'open government' are linked to ICT advancements such as the Internet [32].

Furthermore, the question arises as to why SDI developments fit the governance paradigms so well. Are they determined by these paradigms, or are SDI developments framed into these paradigms in order to gain budget and support? Again, given the complex adaptive nature of SDIs, the answer could be both. In order to better understand SDI evolution, a closer look is needed at SDI governance itself. 


\subsection{SDI Governance Dynamics}

SDI governance is clearly a main driver of SDI advancements, as it delivers in most cases the decisions and budgets needed for development. However, the way SDI governance has evolved and set the development direction of SDIs has not yet been studied in any detail. There appears to be various ways in which SDIs could come to life. Masser [19] distinguishes two groups in his description of the first SDI generation: 'those which are the result of a formal mandate from government and those which have largely grown out of existing geographical information coordination activities' (p. 75). Coetzee and Wolff-Piggott [12] find, based on the SDI literature, that 'SDIs are evolving from top-down, centralized government funded initiatives into decentralized and bottom-up initiatives, but most SDIs are not yet self-organizing and user-driven systems' [12] (p. 124). Lance et al. [33] conclude that in recent years more hierarchy has been introduced in the SDIs of Canada and the USA: 'Hierarchical controls may facilitate coordination to an extent that autonomy-seeking public managers need not automatically disparage such intervention; in fact, they may seek it' [33] (p. 265).

These two conclusions may seem contradictive, but could both be valid for specific SDI cases, given SDIs' complex, adaptive and path-dependent nature [15]. The question is can we qualify SDI governance as adaptive, and how does SDI governance evolve over time.

To answer this question, we assessed the governance evolution of two SDI cases: the Grootschalige Referentiebestand (GRB) of Flanders, Belgium, and the Basisregistratie Grootschalige Topografie (BGT) of The Netherlands. Both are large-scale base maps with all SDI components in place; that is, data, standards, technologies, policies and stakeholders. In both cases, standardised spatial data is collected by companies or governments, put into a central and authoritative database and disseminated via the web to users. This is all supported by an organisational and technical infrastructure. These cases also have very similar goals and objectives, resulting in similar products. However, their history, organisation and governance are very dissimilar. A key reason to choose these cases was their relatively long histories, as the BGT dates back to 1971. Each case will be further described in Section 3, after presentation of the data and research methods in Section 2. Section 3 then delves deeper into the SDI cases, tracing their histories and then synthesising and comparing the two. Section 4 discusses the results of our analysis, and Section 5 presents conclusions.

\section{Methods, Data and Cases}

\subsection{Data Collection}

The study of SDI governance dynamics could be approached using various methodologies, such as interviews, analysis of official documents and surveys. For our purpose of studying the long-term evolution of SDI governance, interviews and surveys were deemed less suitable, as memories can be altered, consciously or unconsciously. Instead, we chose to use written documents, as documents can be considered 'unobtrusive', 'non-reactive' and 'stable' [34] and are therefore suitable for longitudinal analysis [35] (p. 304). We used articles from geo-information and geodetic industry magazines. The benefit of using these magazines is that they are not owned by a specific party and therefore provide a platform for both SDI proponents and critics.

Six Dutch geo-information magazines were selected as research material: Nationaal Geodetisch Tijdschrift (NGT), Geodesia, Geo-info, Vi-Matrix, GeoInside and GeoPlatform (Table 1). The first three were digitally available via an online web archive. The magazines that also covered developments in Flanders (Vi-Matrix, GeoPlatform and GeoInside) had to be manually checked and scanned. 
Table 1. Overview of the Dutch geo-information magazines used as research materials.

\begin{tabular}{ccc}
\hline Magazine & Active Period & Coverage \\
\hline Nationaal Geodetisch Tijdschrift (NGT) & $1971-1979$ & The Netherlands \\
Geodesia & $1959-2003$ & The Netherlands \\
Geo-info & $2004-$ now & The Netherlands \\
Vi-Matrix & $1993-2010$ & The Netherlands and Flanders ${ }^{1}$ \\
GeoInside & $2011-2013$ & The Netherlands \\
GeoPlatform Vlaanderen & $2006-2013$ & Flanders \\
\hline
\end{tabular}

\footnotetext{
${ }^{1}$ Vi-Matrix described geo-information developments in Flanders until 2006, then GeoPlatform took over.
}

Scott [36] proposes four quality control criteria for assessing documentary sources: authenticity, credibility, representativeness and meaning. As we retrieved the magazines directly from the publisher, the documents' authenticity was a given. The credibility of the articles was ensured because major events were in most cases referenced in multiple articles. Furthermore, reactions or rectifications could be expected when authors or editors made a mistake or readers disagreed. As the articles were written in clear Dutch, and the researchers were native speakers of Dutch, there was no difficulty in identifying the meaning of each article, though of course there is always a risk of misinterpretation. We used the total population of available articles, so we can qualify the documents as representative. However, we must note that important governance developments, such as backroom politics, could have remained hidden from this research if they were not referenced in published accounts.

Although the coverage of the magazines was good, especially in The Netherlands, their frequency of appearance had recently diminished. In Flanders, coverage was sparser; the region-specific magazines even stopped publishing in 2013. Moreover, these magazines started a few years after the first large-scale base map developments. Luckily, later articles referred to the starting period, enabling us to form a picture from these secondary sources. As there is often a delay between an event happening and an account of it being published, this method was in effect used on multiple occasions.

As there was no active reporting on Flemish activities in geo-information (GI) magazines from 2013 and later, supplementary interviews were held with two staff members of 'Informatie Vlaanderen' (Information Flanders), which is the current e-government organisation for Flanders. Both staff members were policy advisors on the governance of the Flemish e-government structure, which also included the GRB. The interviews were unstructured. Questions were asked about the establishment of 'Information Flanders' and the current and future governance of the organisation. Because there were still magazines active in The Netherlands, interviews were not necessary to supplement data collection there.

Articles concerning the Dutch large-scale base map (BGT) were found by searching for keywords such as 'GBKN' (Grootschalige BasisKaart Nederland), 'BGT', 'Grootschalige BasisKaart' and 'GBK'. These represent either the name or abbreviation of the current large-scale base map or its predecessors. All articles containing these keywords were selected; only advertisements were ignored. In a similar fashion, articles related to the Flemish large-scale reference map (GRB) were selected by searching for the keywords 'GRB' or 'Cardib'. Because these articles were selected manually, the magazines were double-checked. In total, 877 articles were selected covering the history of the BGT and 176 covering the history of the GRB. Figure 1a,b show the distribution of the articles over time. 


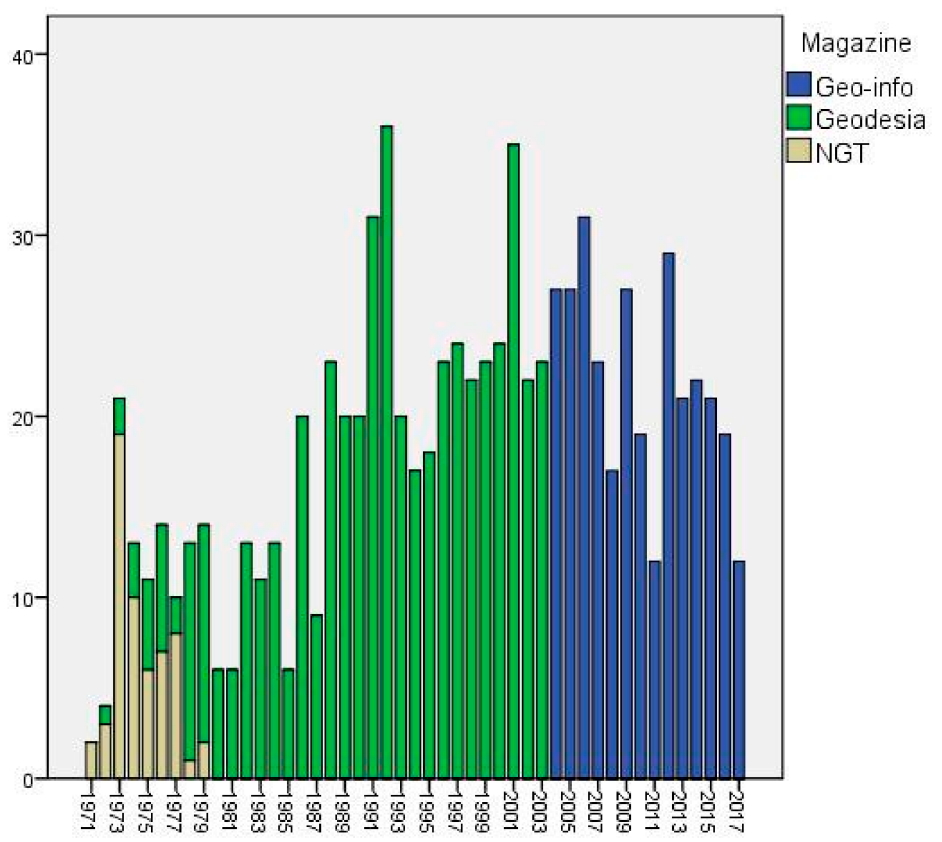

(a)

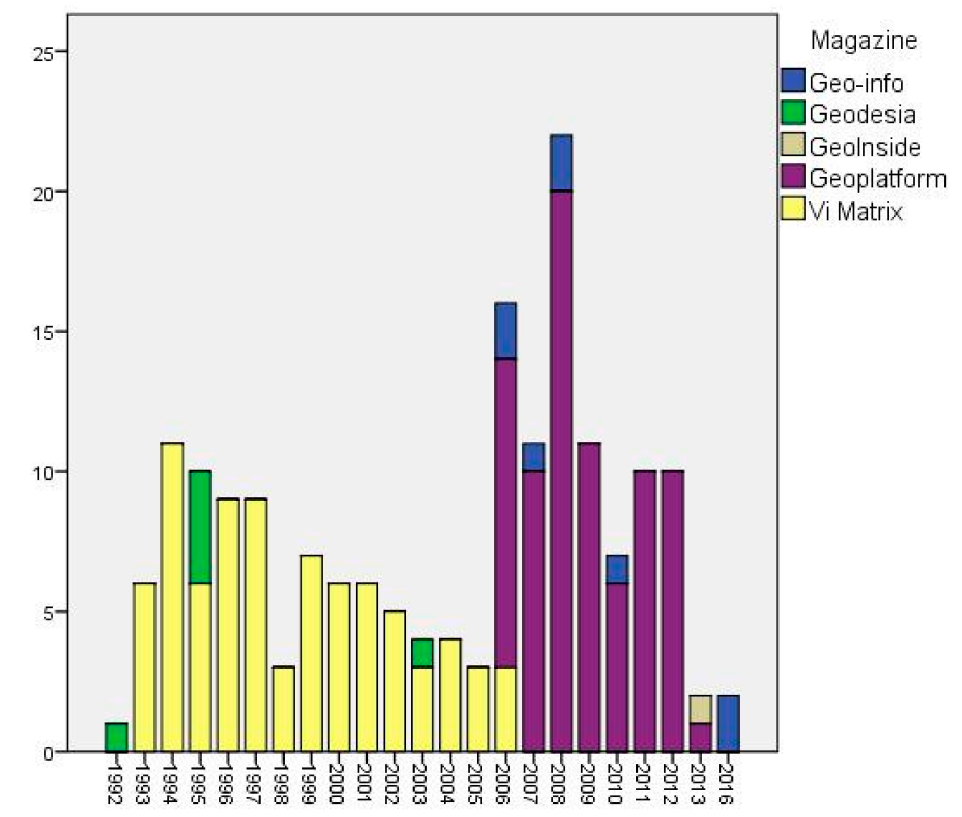

(b)

Figure 1. Distribution of found magazine articles over time: (a) distribution of articles containing BGT-related keywords (The Netherlands); (b) distribution of articles containing GRB-related keywords (Flanders).

\subsection{Data Analysis}

First, the articles were analysed at the meta level. For all articles, the title, publication date, page numbers, article type, authors and author organisations were noted. The author organisations were further aggregated into several higher stakeholder abstraction categories to assess whether the overall picture was overly distorted by one stakeholder group. These categories, in most instances, were naturally formed, based on the stakeholders represented in the articles. For example, all utility companies were categorised as 'utility', and all government entities, except central government organisations, were grouped in the 'local government' category. Organisations that were not aggregated 
were the Dutch 'Cadastre' for the BGT case and 'AGIV' (Agency for Geo-Information Flanders) for the GRB case, as these organisations were highly involved in the creation of the large-scale maps (see Section 3).

Associations and foundations were aggregated into three categories: 'associations', 'interest groups' and 'partnerships'. The category 'partnerships' includes official collaborations in which organisations worked closely together (or even joined up) to achieve their common goals. 'Interest groups' consist of lobby organisations for governmental organisations or private companies. 'Associations' comprise geo-information or geodetic associations for knowledge sharing.

Articles written by multiple authors from different stakeholder categories were classified as 'mixed'. Figure $2 \mathrm{a}, \mathrm{b}$ present relative distributions of the author affiliations aggregated into case-specific stakeholder categories.

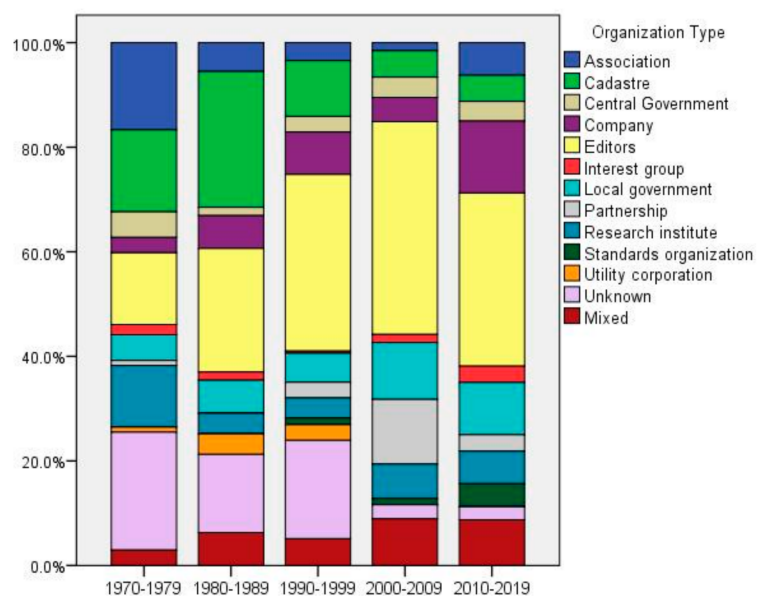

(a)

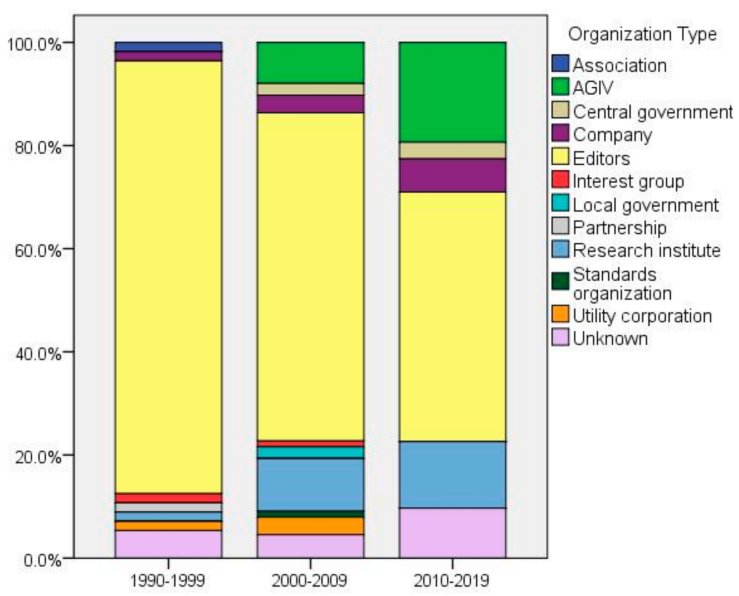

(b)

Figure 2. Relative distribution of article author affiliations, categorised into case-specific SDI groupings per decade: (a) distribution of BGT-related articles (The Netherlands); (b) distribution of GRB-related articles (Flanders).

It should be noted that the GRB-related articles were much more likely to be written by reporters and editors, as these magazines had a more journalistic character. Furthermore, the division seems balanced, as certain increases or decreases of particular stakeholder categories can be explained by the development of the SDI (described in Section 3).

Following the meta-analysis, the titles and content of articles were scanned and read in-depth if they contained organisational information on the SDI. This information provided the basis of the case descriptions, while simultaneously providing a window for the study of the SDI governance evolution in each case. To make the analysis transparent, references were documented in the case descriptions (Section 3). These refer to the list of articles used in Appendix A.

We then synthesised and compared our findings from the cases. Our analysis focused on two governance ingredients: actors and interactions. As stated in the introduction, institutions, both formal and informal, are also an important governance ingredient. However, informal institutions, such as cultures, values and beliefs, proved particularly difficult to distinguish from the magazine articles. Findings on formal institutions, such as laws, policies and organisations, are covered in the sections on interactions and actors. 


\section{Results}

\subsection{The Netherlands: Key Registry Large-Scale Topography (BGT)}

The history of The Netherlands' Key Registry Large-Scale Topography (BGT) dates back to the early 1970s. In 1971, a commission of scientists, governments and utility companies investigated the need for a uniform cable and pipe registration system (1971a). The conclusions of that study yielded a new commission, which studied the need for a uniform large-scale base map that could also serve as a reference map for the cable and pipe registry (1971b; 1972a; 1972b). In 1974, the report of this second commission was released, deeming the uniform base map feasible (1973a; 1974a). The commission made several proposals for realisation, suggesting among other things standards, techniques, stakeholders and a governance framework (1973a; 1973b; 1973c; 1974a). Although there were votes to create this map digitally (1973d; 1973e; 1973f), the maps and its production were ultimately analogue-based.

As often seen during the 'golden age of planning' [6], the advice of the experts and scientists was followed. In 1975, a Royal Decree launched the creation of the Grootschalige Basiskaart Nederland (GBKN; 'Large-Scale Base Map of The Netherlands') (1975a; 1975b). As proposed in the commission report, the Ministry of Housing and Spatial Planning gave the Dutch Cadastre the task of creating the map. The Central Mapping Board was officially installed in 1976, made up of stakeholders including utility companies, local government, the Cadastre, topographic bodies and ministries (1976a; 1976b). The goal of this Board was to determine priorities, allocate funds and develop standards and techniques (1974a; 1975a; 1975b; 1976a; 1976b). Provincial mapping boards, coordinated by the regional bodies of the Cadastre, were to facilitate regional collaboration and provide input to the Central Mapping Board (1974a; 1978).

In 1975, the first GBKN project began (1976c; 1976d; 1977). However, with the exception of a few regions, map production did not go well (1980). The first governance intervention came in 1983. A government ICT report advised greater focus on regulation, instead of consultation. Furthermore, it recommended that the Ministry create an organisation that could coordinate and facilitate all geo-ICT developments: the Board for Property Information (RAVI). The Central Mapping Board objected to the report's conclusions, noting that consultation remained crucial for such a big and expensive task (1983; 1984a; 1984b). The ministry listened: RAVI replaced the Central Mapping Board, but the original collaborative structure of the GBKN project remained at the level of the provincial mapping boards (1987a). Articles foreseeing further regulation were included in the preparation of a new Cadastre law (1985a).

Meanwhile, New Public Management (NPM) made its entrance. Government demanded that the Cadastre cover its own costs (1984c; 1984d; 1985b; 1989a). Budgets shrank (1986a), and local standards emerged to make the mapping feasible in regions where there were not enough partners (1986b). Criticism swelled from municipalities (1984d; 1989b; 1990a; 1990b) and the utility companies (1989c), as they considered the regional Cadastre offices as behaving too autonomously.

Around 1991, the Secretary of State of the Ministry of Spatial Planning and Environment intervened. The Cadastre's financial situation was poor and the Secretary of State demanded it make severe cuts (1991a). Creation of the GBKN was one of the reasons for the Cadastre's losses (1987b; 1988), and only 30\% of the country was covered (1992b). The Ministry determined that the GBKN would no longer be a primary Cadastre task (1991b; 1992a). GBKN articles were scrapped from the Cadastre law in 1992 (1991c; 1992a; 1992c). The national government was no longer willing to participate in the GBKN (1992b).

This could have been the kill switch, but it was not. Regional public-private partnerships were formed to create and maintain the GBKN in the regions (1992b; 1992d). The Cadastre became a partner instead of a coordinator. The national government provided 10 million guilders (4.5 million euros) for better organisation and collaboration for the GBKN. A foundation was set up which would coordinate GBKN activities nationwide: the National Partnership GBKN (1992e; 1993a; 1993b; 
1993d). The municipalities' position was strengthened, and as they could choose to either do the map production alone or operate in a public-private partnership mode (1993a). Moreover, a goal was set: the GBKN was to cover the entire country within 10 years (1993b; 1993c).

During the 1990s, GBKN production soared (1999a; 2000a). However, a fierce debate also emerged. The GBKN standard was line-oriented, for use in computer-aided design (CAD) systems, but users demanded object-oriented data, which worked better with geographical information systems (GIS) (1993e; 1995a). An object-oriented GBKN was promulgated as a cure for the regional diversity in GBKN data (1995a; 1995b). After some years of feasibility research and discussion (1996a; 1996b; 1997a; 1997b; 1997c; 1997d), the National Partnership decided not to invest in this, but to focus instead on completion and other ways to standardise the product (1998). In 2001, the GBKN was finished (2001a). Now that the map was complete, the National Partnership repositioned itself (1999b; 2000b; 2003a; 2003b). Goals were set for updating and standardising the product, conducted by the regional partnerships (2000b; 2001b; 2001c).

Meanwhile, the concept of 'authentic registries' emerged in government policy in The Netherlands (2002a; 2002b). An 'authentic register', later called a 'key registry', is a registration system formally appointed by government with legally mandated quality standards for use by government. The National Partnership saw it as an important goal that the GBKN become a key registry, as this would provide it a clear legal status and organisational and financial framework, while acting as an accelerator for standardisation (2002c). Although several other governmental spatial datasets were already considered 'key registries', the GBKN had to wait (2002d; 2003c). After all, creating a uniform GBKN would be quite costly (2006b) and support from many organisations was needed (2003c).

During the ensuing years, some municipalities independently created their own object-oriented large-scale base maps (2002e; 2003d; 2003e). However, becoming a key registry remained an important motivator for these organisations to join the National Partnership in its lobby (2003d; 2003e; 2003f). After an exploratory phase (2006a) and successful budget claim in 2008 (2009a), the mandate was given by the national government to transform the GBKN into the Basisregistratie Grootschalige Topografie (BGT; 'Key Registry Large-Scale Topography').

In 2009, a declaration of intention was signed by all partners creating the object-oriented BGT standard (2010). Interestingly, although the Cadastre and utility companies had done much in the past to create the GBKN, the BGT was created by government organisations alone (2009a; 2009b). However, because of the decentral organisation, some 450 governmental organisations were involved (2011; 2012a). The Cadastre was to continue to maintain the central database (2012b) and the National Partnership GBKN was transformed into the Partnership of BGT Key Registry Holders (2012c). Because key registries were created by government and because the BGT was declared open data, public utility companies no longer had to invest in the BGT (2009a; 2012a). However, as a main user, they did retain their position in steering groups (2009a).

In 2012, the BGT standard and law were finished (2013) and the key registry holders began to build the BGT (2014). The task was set for completion by the start of 2016 (2012a), but the second half of 2017 currently seems the likely completion time [37]. Now that the BGT is almost finished, efforts are being made to improve cohesion of the BGT with other datasets within and between organisations (2017a; 2017b).

\subsection{Flanders: The Large-Scale Reference Map (GRB)}

The origin of the GRB is two-pronged. One prong can be traced to the 'Cardib' initiative. Cardib was a public-private partnership erected in 1990 by four small public utility companies with the goal of creating a large-scale base map of Flanders. Together with its Walloon counterpart, Bicard, Cardib had agreed that the company Bicardib would do the data creation (Bicardib fulfilled this role for both partnerships) (1993f). One of the company's founders and shareholders was Eurosense, which was considered a monopolist in aerial photography (1993f; 1993g). 
Although some other public utilities joined, Cardib gained momentum in 1992, when it diminished the influence of Eurosense and two large private utility companies showed interest and joined (1993g; 1994a). At least three interested organisations in a region were needed to create a Cardib map (1994b). Although the initiative united some organisations, only 3.8\% of Flanders was covered by a large-scale map at the start of 1997 (1997e). Another issue was that, despite agreements, these covered areas were not updated (1997f). This was reason for the two private companies to leave the initiative (1997f; 1997g). In 1999, the last Cardib project was finished and the initiative was declared bankrupt. 'GIS Flanders' took over all available data and aerial imagery (1999c).

GIS Flanders had started out at the end of the 1980s as a working group to study the GIS needs of federal government departments. It advised in 1991 putting in a huge order to Eurosense, to purchase aerial imagery for the whole Flanders region. This order was blocked, however, by the Financial Inspection department and later by the Flemish Parliament (1993g). GIS then became a politically sensitive issue and all investments were barred [38] (1993g; 1993h; 1994c). In 1993, after showing their dissatisfaction in local media, a group of GI professors was asked by the Flemish government to consult on the development of a Flemish spatial data infrastructure. The group designed a governance structure, with a technical centre, a geo-information board and a coordinating minister. It was to serve not only the federal level but interests at all administrative levels (1993i). After almost two years of meetings and negotiations (1994d; 1994e; 1994f; 1995c), the designed organisational structure was officially adopted in 1995 (1995d). The technical centre, now called 'Support Centre', expressed interest in joining the Cardib initiative (1997g), but, by the time it was fully operational, Cardib was defunct (1999c).

The Support Centre designed a new model for a large-scale base map: the Grootschalige Referentiebestand (GRB; 'Large-Scale Reference Map'). Feasibility was a key issue in the design choices for this map (1999d). After a long period of preparation (1999e), the Flemish parliament approved the GIS Flanders decree in 2000, which gave the Support Centre legitimacy (1999c; 2000c). With this decree, the preparations for the GRB also gained more solid footing, and design choices were made, pilot projects implemented and funding sought (2001d; 2002f).

In April 2004, the GRB decree was signed (2005; 2006c), setting out all the organisational preconditions and commitments needed to create and maintain the GRB, such as scope, standards, budgets and governance. Utility companies brought in around $50 \%$ of the funding, gaining considerable influence in return, as they were the only stakeholders in the GRB Board. The Flemish government funded the other half $(2004 ; 2005 ; 2006 \mathrm{~d})$.

In 2006, the Support Centre was reorganised into an independent entity: the Agency for Geo-Information Flanders (AGIV) (2006d). AGIV scaled up production of the GRB (2009c), and, in 2013, the GRB was successfully completed according to plan. In late 2015, the GRB was declared open data (2016). At the start of 2016, AGIV merged with several other e-government services to form the new agency 'Informatie Vlaanderen' ('Information Flanders'). Efforts are currently under way to further integrate governance of SDIs, such as the GRB, into a new governance model encompassing all e-government information (interviews).

\subsection{Comparing the Governance of the Two Cases}

When we compare the governance evolution of the GRB and its predecessor with the BGT and its predecessor, we must first conclude that SDI governance is definitely not static. From the Royal Decree in 1975 up to the BGT of 2017, the governance structure changed some six times, often quite radically (Table 2). Although the GRB initiative is younger, SDI governance also changed considerably in this case (Table 2). 
Table 2. Important governance transition moments in the Key Registry Large-Scale Topography (GBKN/BGT) case in The Netherlands and the Large-scale Reference Map (Cardib/GRB) case in Flanders, Belgium.

\begin{tabular}{|c|c|c|c|}
\hline Year & Governance Changes BGT & Year & Governance Changes GRB \\
\hline 1975 & Royal Decree GBKN & 1990 & Start of Cardib \\
\hline 1982 & End of the Central Mapping Board & 1992 & $\begin{array}{c}\text { GIS Flanders intervention } \\
\text { by Minister }\end{array}$ \\
\hline 1992 & $\begin{array}{c}\text { Cadastre and national government } \\
\text { pull-back, start of } \\
\text { public-private partnerships }\end{array}$ & 1999 & End of Cardib, start of GRB \\
\hline 2008 & Start of BGT programme & 2004 & GRB official decree \\
\hline 2012 & New governance for transition to BGT & 2007 & Start of AGIV ${ }^{1}$ \\
\hline 2017 & $\begin{array}{c}\text { New governance structure for greater } \\
\text { cohesion between spatial } \\
\text { key registries }\end{array}$ & 2015 & $\begin{array}{l}\text { Integration of GRB in e-government } \\
\text { services, establishment of } \\
\text { Information Flanders }\end{array}$ \\
\hline
\end{tabular}

\subsubsection{Interactions}

Interestingly, both large-scale base maps seem to have emerged from collaborative network activities rather than top-down coordination. The GBKN had formal top-down status in 1975 but lost that in 1992. The GRB only became official in 2004, 14 years after the first collaborative large-scale mapping activities.

Another similarity between the GRB and BGT is that both experienced a period in which the whole undertaking was in jeopardy. For the BGT, this was around the start of the 1990s, when the Ministry demanded that the Cadastre cut its GBKN outlays and revoked the GBKN's legal status. At around this same period, the Minister intervened in Flanders, blocking further GI investments. Both interventions seemed to act as a wake-up call for the interested parties, telling them that they needed each other to move forward.

The governance response to these interventions was opposite in the two different regions. In Flanders, the project evolved from governance with network and market type mechanisms to governance with more hierarchy and network type mechanisms. In The Netherlands, it moved from network and hierarchy type mechanisms to network and market type mechanisms in the 1990s. The later transition to the BGT, however, again brought hierarchy and network type mechanisms.

When the base maps became 'official authentic registries' and were incorporated into a larger digital national roadmap, the presence of hierarchical steering instruments increased. Figure 3 illustrates the rise and decline of hierarchical instruments in the cases. The graph was built as follows: for every hierarchical instrument found in the cases, a weight equal to 1 was added. The following hierarchical instruments were found: a law or decree, a central coordinating board, a central government with ultimate responsibility, a central government actively involved in decision-making, $50 \%$ or more of the SDI being centrally financed and mandatory standards. Although the graph should be interpreted schematically - as we would not suggest that our 'counting' of hierarchical instruments is complete-it nonetheless shows that over time hierarchical instruments became more prevalent in these SDIs.

Both large-scale base maps currently share a similar kind of interaction governance, with hierarchical steering such as a legal framework and a coordinating body in place, as well as network steering with the formation of several working groups and steering committees made up of all kinds of stakeholders. In addition, market type mechanisms are in place. The market is involved as a generator of the data and as a software provider, in most cases via tender procedures. However, hierarchical and network steering dominate in both SDI cases. 


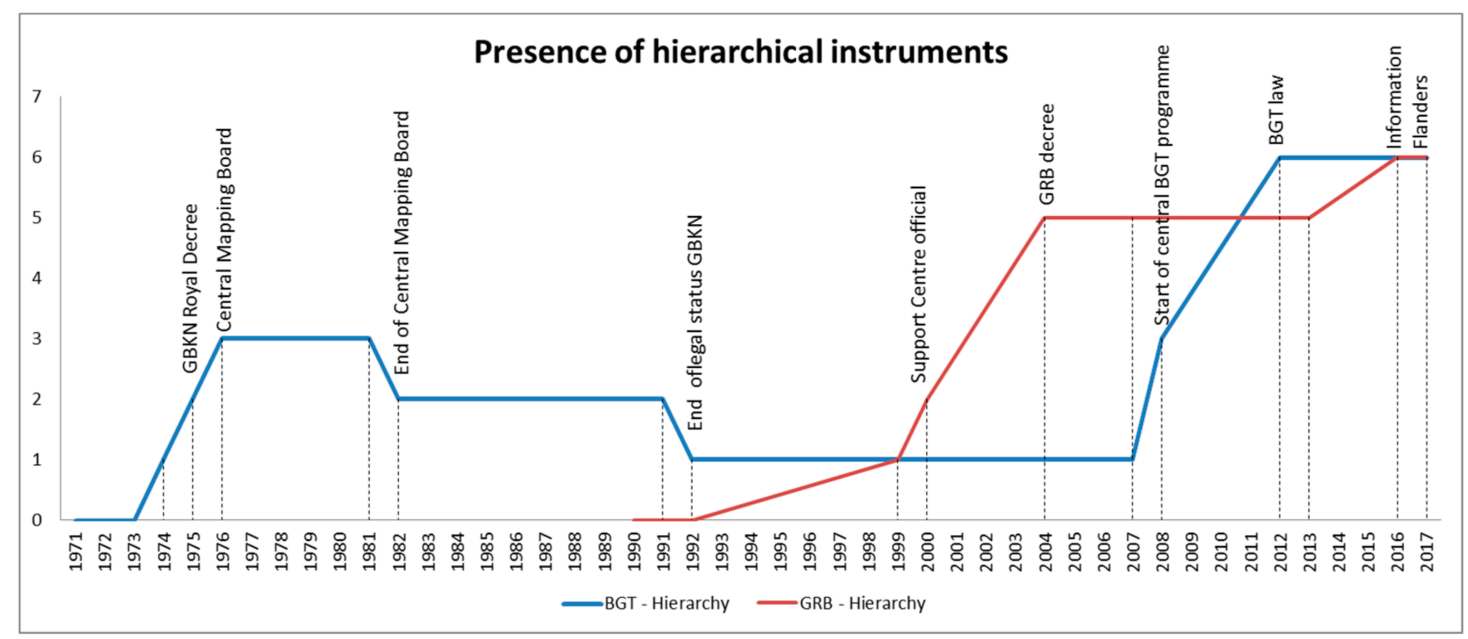

Figure 3. Presence of hierarchical instruments in the SDI cases: 1971-2017 BGT (The Netherlands) and 1990-2017 GRB (Flanders). Labels are in reference to key moments in the development of the specific large-scale base map.

\subsubsection{Actors}

Another remarkable finding is the constant repositioning of stakeholders. This is most obvious in the division of the budgets. For production of the GBKN, in 1975, the Cadastre provided 50\% (partly covered by a ministerial budget) and municipalities and public utilities together contributed $50 \%$. After 1992, this changed. The Cadastre provided only $20 \%$, municipalities provided $20 \%$ and public utilities contributed $60 \%$. After a reshuffle in 2003, the new division became $20 \%$ for the Cadastre, $30 \%$ for the municipalities and $50 \%$ for the public utilities, though a consultancy company calculated a fair division as $24 \%$ Cadastre, $41 \%$ municipalities and 35\% public utilities (2012d). With the BGT, the division between partners is less easily determined. The municipalities are responsible for the production process, and they get compensation from the central government, which also financed the necessary spatial data infrastructure. Together, they largely pay the bill for the BGT.

In Flanders, the Cardib initiative came mainly from public and private utility companies, sometimes with participation of interested municipalities. Before 1992, GIS Flanders was only for the central government, but the initiative was later opened to all government layers. When the GRB came about, the government needed input from the utility companies. They were mandated by law to pay some $50 \%$ of the budget. The Flemish government paid the other $50 \%$. Municipalities do not have to bring any money, but, in order to diminish the costs of the updating process, they are legally required to deliver feedback and as-built information from newly constructed areas.

In both large-scale mapping processes, we found a growing importance of municipalities in creating and updating large-scale maps. Furthermore, the SDI stakeholders in both cases clearly learned from their past experiences. This was mentioned in the articles too, as the past was sometimes used to highlight how things had improved. Furthermore, the two cases learned from each other. Recall that Figure $1 \mathrm{~b}$ showed articles about the GRB appearing in magazines covering only The Netherlands. Texts such as 'Let's finish the GRB quicker than the GBKN' and 'The Belgians do it better' enjoined SDI stakeholders to improve.

\section{Discussion}

\subsection{Self-Organisations}

The notion from Coetzee and Wolff-Piggott [12] that SDIs are not yet self-organising and are mainly top-down structured seems not to apply to these two cases. Stakeholders in both cases reorganised their governance from time to time, especially when challenges arose and frustration with the product or 
process reached a boiling point. However, Coetzee and Wolff-Piggott [12] also observe that 'the Dutch SDI development model is voluntary and its success lies in the strong self-organizing ability of the geospatial information community' (p. 124). Kok and Van Loenen [39] similarly stress the importance of self-organising abilities, characterising the Dutch community as 'active'. Adaptive governance capacity is probably much weaker if self-organising abilities are less prevalent within the geospatial community [15].

Culture could be an important factor in these self-organising abilities. However, it should be noted that, despite The Netherlands and Flanders sharing the same language, their cultures are rather different. The culture of Flanders can be seen as its own cultural cluster, seemingly most closely related to Sweden, though they do not share much history [40]. Further research on adaptive SDI governance in different countries and cultures could point out whether the reorganisation of SDI governance is culturally dependent, and if such a self-organising evolutionary trajectory is unique or a worldwide phenomenon.

The high cost of making a large-scale map is another possible reason why self-organisation emerged in these two cases, perhaps rendering network cooperation inevitable. Collaboration between public utility companies and local and central governments was necessary to make a large-scale map financially feasible. Other governmental spatial datasets, such as small-scale topography and land administration, are organised in a much more top-down fashion, both in Belgium and in The Netherlands.

Interesting in this respect is the relative absence of private parties in these initiatives, with the exception of privatised utility companies. The GRB did have a market-oriented start with the Cardib project, but that project failed to serve the interests of all stakeholders. The struggle for market collaboration in public-private partnerships is not unique to these SDIs. It has been documented in other financially costly initiatives, such as the European space programme Galileo [9,41]. More research on the market-government SDI relation may be helpful for improving collaboration or shedding light on potential problems. Furthermore, the influence of non-governmentally owned SDIs and their 'governance' could be an interesting research angle, as these bring (public) SDIs closer to end users.

Of course, the long history of GI collaboration in these regions could have fostered self-organisation. Note that it took from 1974 until 2001 to complete the GBKN. It took 23 years, from the first Cardib ideas in 1990 until 2013, to complete the GRB. In addition, it took 25 years to advance from the first ideas for an object-oriented GBKN, in 1992, to the slated completion of the object-oriented BGT, in 2017. In all cases, the last ten years were the most productive. These productive years were sparked by a shared realisation that the current path would ultimately lead to SDI failure.

This does not seem unusual for spatial data infrastructures. Koerten [31] studied, next to the GBKN, the development of the Dutch National SDI. At the time of his research, that project had suffered repeated failure, attributed to an overemphasis on technology and innovation. Upon the launch of yet another attempt, Koerten mused sceptically that 'the Dutch geoinformation sector is still not inclined to look back and learn from the past' [31] (pp. 175-176). Today, however, the Dutch National SDI is thriving, and its usage has grown almost exponentially in the years since 2014 [42]. Again, this success came 20 years after the first proposals for the project and repeated false starts. As SDIs do not come in dozens there is no 'survival of the fittest', but (impending) failure does seem to have a simulative effect. Alas, this trajectory costs time and money.

According to Jessop, 'given the growing structural complexity and opacity of the social world, failure is the most likely outcome of most attempts to govern it in terms of multiple objectives over extended spatial and temporal horizons-whatever coordination mechanism is adopted' [43] (p. 106). This suggests the need for further research on the possible fly-wheel effect of the threat of imminent SDI failure. 


\subsection{Mix of Governance Interactions}

This study's findings show remarkable resemblance to the conclusion of Lance et al. [33] in their study of two SDI cases in Canada and the USA. They found a growing importance of central coordination and a movement away from autonomous SDI stakeholders in favour of formal top-down recognition. Their conclusion is as follows:

The use of hierarchical controls ... runs contrary to the public management discourse on network governance, which purports that informal, horizontal networks are replacing formal, vertical/hierarchical organization. However, a shadow of hierarchy may actually facilitate the 'joining up' of government geospatial information systems. [33] (p. 265)

The fact that SDIs nowadays have more hierarchal controls, both in North America and in The Netherlands and Belgium, does not automatically mean that SDIs are now governed in an overtly authoritarian manner. Vancauwenberghe, in fact, notes an attempt to introduce more network coordination within the Flemish SDI [2]. The histories of the two large-scale base maps studied here suggest that harmonious collaboration is more important to move ahead than autonomy. Other coordination mechanisms such as markets and networks are also still present. Academics (e.g., [10,44,45]) increasingly agree that such a mixture of governance forms is important for achievements or results: 'Continuously steering towards interaction, participation and consultation tends to produce inertia; over-emphasis on hierarchical top-down control has the disadvantage of driving parties to dig in their heels, leading to resistance, delays and postponements of implementation' [45] (p. 185).

Not coincidentally, a mixture of governance forms is one of the three prescriptions of what is called 'adaptive governance' [44]. The other two are analytic deliberation and nesting. Analytic deliberation concerns formation of well-structured dialogue by including different kinds of actors with different interests and perspectives. By keeping them informed and around one table, trust is said to flow more easily and consensus is produced for dealing with conflicts. Nesting refers to the layering of institutional arrangements. This makes arrangements complex and redundant, but this is necessary, as simple governing strategies like 'command and control' often fail in complex systems [44].

Can the SDI cases in this research be considered perfect examples of adaptive governance? Probably not, as radical governance changes were sometimes needed to improve. However, both cases evolved towards use of a broader interaction mix, with more stakeholders involved and also the broadest set of laws, policies and standards applied. Therefore, it could be that, with the help of self-organisation, SDI governance automatically advances towards a more adaptive form. Further research is needed to confirm this.

\section{Conclusions}

Based on the key governance transitions found in the two cases, we can conclude that SDI governance is adaptive, as it changed considerably during the evolution of the two registries. However, we can also conclude that most governance models did not hold up very long, as they either were not meeting their goals, were not satisfying all actors or were not in alignment with new visions and ideas. Nothing, not even legal requirements, could withstand the need for a change in SDI governance.

The general notion that network governance is a contemporary phenomenon is contradicted by the origins of both our SDI cases, as both emerged from network collaboration. Their governance evolution thereafter differed. GBKN/BGT governance transformed from an hierarchy-network organisation towards a mainly market-network driven governance in the 1990s under the influence of New Public Management and poor financial and production performance. The GRB accumulated more and more hierarchical influences over the years as it gained legitimacy. This also later happened to the BGT when it gained the status of 'key registry'. This supports the finding of Lance et al. [33] that hierarchical controls are increasing within SDIs. 
This does not mean that SDIs are now governed in a purely top-down fashion, as other governance forms, such as networks and markets, are still present and important. It merely shows that central governments are taking SDIs more seriously and expanding their steering possibilities to govern SDIs more effectively, which also improves its adaptive capacity. However, self-organising abilities of SDI actors also seem an important precondition for successful adaptive SDI governance. By applying both in SDI governance, SDI's survival seems to be ensured for the future.

Acknowledgments: The authors thank Hollandse Cirkel, Geo-informatie Nederland (GIN) and VBK Content for providing access to their magazine archives. In addition, we would like to thank our reviewers for their elaborate feedback. This work was supported by the Nederlandse Organisatie voor Wetenschappelijk Onderzoek (NWO).

Author Contributions: Jaap-Willem Sjoukema conducted the research and wrote the paper. Arnold Bregt and Joep Crompvoets helped set up the research goals and design, provided suggestions and reviewed the paper.

Conflicts of Interest: Jaap-Willem Sjoukema was employed part time from October 2015 until June 2017 at the BGT Programme Office of the Dutch Ministry of Infrastructure and Environment. He is currently employed part time at Wageningen University, where this research was conducted. The BGT Programme Office exercised no influence on the research or its findings. The authors declare that no conflict of interest was involved.

\section{Appendix A}

Geo-information magazine articles referred to in the case descriptions (Section 3):

- 1971a, Studiecommissie Leidingenregistratie. Rapport Studiecommissie Leidingenregistratie. NGT, Vol. 1971, No. 05, pp. 91-105.

- 1971b, D.L. Rodrigues Lopes. De studiedag leidingenregistratie. NGT, Vol. 1971, No. 09, pp. 148-153.

- 1972a, G.A. van Wely. Grootschalige basiskaart van Nederland. Geodesia, Vol. 1972, No. 07, p. 200.

- 1972b, G.A. van Wely. Grootschalige basiskaart van Nederland. NGT, Vol. 1972, No. 09, pp. 144-145.

- 1973a, M.J.M. Bogaerts, G.F. de Witt, C. Koeman, G.A. van Wely, W.A. Claessen, S. Rienstra, J.A.C.E. van Roermund. Interimrapport Commissie Grootschalige basiskaart. NGT, Vol. 1973, No. 09, pp. 130-135.

- 1973b, C. Zeillemaker. Voorstellen voor de normalisatie van de bladindeling, het formaat en de nummering van grootschalige (1:2000 tot 1:500) topografische kaarten. NGT, Vol. 1973, No. 10, pp. 159-165.

- $\quad 1973 c$, C. Koeman. Voorstel voor bladindeling, het formaat en de nummering van de Nederlandse grootschalige kaart. NGT, Vol. 1973, No. 12, pp. 212-215.

- $\quad$ 1973d, J. Dubbeld. Digitaal kaarteren. NGT, Vol. 1973, No. 05, pp. 85-95.

- $\quad$ 1973e, Projectgroep '73. Digitale basiskaartering. Geodesia, Vol. 1973, No. 06, pp. 130-131.

- 1973f, Projectgroep '73. Het rapport 'Digitale Basiskartering' van de projectgroep '73 van de onderafdeling der Geodesie, TH-Delft. NGT, Vol. 1973, No. 09, p. 141.

- $\quad$ 1974a, M.J.M. Bogaerts, G.F. de Witt, C. Koeman, G.A. van Wely, P.A.M. de Vos, J.B. van Reij, W.A. Claessen, S. Rienstra, A. Waalewijn, J.A.C.E. van Roermund. Rapport van de commissie Grootschalige basiskaart. NGT, Vol. 1974, No. 11, pp. 219-237.

- $\quad$ 1975a, Editors. Grootschalige Basiskaart. Geodesia, Vol. 1975, No. 07, pp. 186-187.

- $\quad$ 1975b, Editors. Grootschalige Basiskaart. NGT, Vol. 1975, No. 09, pp. 145-146.

- $\quad$ 1976a, J.P. Gruijters, G.A. van Wely. Installatie centrale kaarteringsraad. Geodesia, Vol. 1976, No. 03, pp. 90-93.

- $\quad$ 1976b, J.P. Gruijters. Installatie centrale kaarteringsraad. NGT, Vol. 1976, No. 03, pp. 57-58.

- $\quad$ 1976c, W.A. Claessen. Grootschalige Basiskaart ‘het Bildt. Geodesia, Vol. 1976, No. 02, pp. 58-59.

- $\quad$ 1976d, W.A. Claessen. Grootschalige Basiskaart ‘het Bildt. NGT, Vol. 1976, No. 02, p. 38.

- $\quad$ 1977, P. Plantinga. GBKN proefproject het Bildt. NGT, Vol. 1977, No. 06, pp. 97-109. 
- 1978, G.A van Wely. De vorming van Provinciale Kaarteringscommissies. Geodesia, Vol. 1978, No. 05, pp. 127-130.

- 1980, Unknown. Jaarverslag 1979 Voorlopige Centrale Kaarteringsraad. Geodesia, Vol. 1980, No. 11, p. 435.

- 1983, Unknown. Advies van de voorlopige Centrale Kaarteringsraad. Geodesia, Vol. 1983, No. 09, p. 283.

- 1984a, J. Mol. Heeft het Structuurplan Topografie en Leidingen van de BOCO zin? Geodesia, Vol. 1984, No. 01, pp. 9-11.

- $\quad$ 1984b, Unknown. Jaarverslag 1983 Voorlopige Centrale Kaarteringsraad. Geodesia, Vol. 1984, No. 09, pp. 311-312.

- $\quad 1984 c$ c, P. van der Molen. Privatisering van overheidstaken op het gebied van de landmeetkunde en kartografie. Geodesia, Vol. 1984, No. 07, pp. 248-254.

- $\quad$ 1984d, A.J.G. Zinken. Decentralisatie kadastertaken. Geodesia, Vol. 1984, No. 10, pp. 345-347.

- $\quad$ 1985a, J.L.G. Henssen. De ontwerp-Kadasterwet. Geodesia, Vol. 1985, No. 11, pp. 386-390.

- 1985b, C.J. Remijnse. Het Kadaster als producent en verstrekker van vastgoedinformatie. Geodesia, Vol. 1985, No. 12, pp. 440-441.

- $\quad$ 1986a, F.B.. Uit de Nieuwjaarstoespraken. Geodesia, Vol. 1986, No. 03, pp. 102-103.

- $\quad$ 1986b, Adri den Boer. GBKN-B een haalbare kaart. Geodesia, Vol. 1986, No. 06, pp. 224-225.

- $\quad$ 1987a, Peter Miete. Het grote geld. Geodesia, Vol. 1987, No. 12, p. 526.

- $1987 b$, J.B. van der Veen. De ontwikkeling van de GBKN in Overijssel. Geodesia, Vol. 1987, No. 02, pp. $47-51$.

- 1988, Editors. Onderzoek naar gebruik en kosten van de grootschalige basiskaart Nederland. Geodesia, Vol. 1988, No. 07, p. 348.

- $\quad 1989$ a, J.W.J. Besemer, F.v.d. Gaag, W. van Pijkeren, J.H.J.M. Vos. Het Kadaster op weg naar de formatie 1990. Geodesia, Vol. 1989, No. 04, pp. 166-170.

- 1989 b, L.A.H. Boeije. De toekomstige rol van de grootschalige basiskaart bij de gemeente. Geodesia, Vol. 1989, No. 02, pp. 71-76.

- 1989c, G.P.F. Pistorius. De relatie tussen de nutsbedrijven en de GBKN. Geodesia, Vol. 1989, No. 03, pp. 124-126.

- 1990a, J.G. Versteeg. Een pleidooi voor een betere bijhoudingsregeling GBKN. Geodesia, Vol. 1990, No. 03, pp. 114-118.

- $\quad$ 1990b, C. Zeillemaker. Gemeenten en topografie. Geodesia, Vol. 1990, No. 09, pp. 369-373.

- 1991a, Unknown. Privatisering Kadaster nu op een laag pitje. Geodesia, Vol. 1991, No. 01, p. 84.

- $1991 b$, J. Besemer, Wim van Pijkeren, Theo Scheele. De (onzekere) toekomst van het Kadaster. Geodesia, Vol. 1991, No. 06, pp. 258-261.

- 1991c, Editors. Kadaster. Geodesia, Vol. 1991, No. 12, p. 555.

- 1992a, Adri den Boer. Ministerraad akkoord met wetsvoorstel verzelfstandiging Kadaster. Geodesia, Vol. 1992, No. 07, pp. 310-311.

- $\quad$ 1992b, Berry van Osch. GBKN-overleg in impasse?. Geodesia, Vol. 1992, No. 04, pp. 160-163.

- $\quad$ 1992c, P. Schreuder, Z. Klaasse. Kadasterwet. Geodesia, Vol. 1992, No. 09, pp. 344-353.

- $\quad$ 1992d, R. Morrema. GBKN-PPP Op weg naar publiek private samenwerking. Geodesia, Vol. 1992, No. 04, pp. 142-146.

- 1992e, Unknown. Samenwerkingscontract Grootschalige Basiskaart van Nederland ondertekend. Geodesia, Vol. 1992, No. 12, p. 535.

- $\quad$ 1993a, Editors. De strijd om tien miljoen. Geodesia, Vol. 1993, No. 05, p. 227.

- 1993b, J. Kats. Grootschalige Basiskaart van Nederland: strijd om tien miljoen?. Geodesia, Vol. 1993, No. 09, p. 425. 
- 1993c, F. Molenaars, J.A. Schaart. GBKN een zorgenkind volwassen. Geodesia, Vol. 1993, No. 04, pp. 160-164.

- $\quad$ 1993d, W.H. de Vos. Landelijk Samenwerkingsverband GBKN. Geodesia, Vol. 1993, No. 11, pp. 558-564.

- $\quad$ 1993e, J.H. van Oogen. Terreinmodel Vastgoed. Een algemene classificatie voor ruimtelijke objecten. Geodesia, Vol. 1993, No. 10, pp. 486-490.

- 1993f, Peter Mom. Over jaar of 10 is gans Vlaanderen gecardibd. Vi Matrix, Vol. 1993, No. 12, pp. 10-13.

- 1993g, Peter Mom, Vera Dua. Gewest zal nooit over eigen basisgegevens beschikken. Vi Matrix, Vol. 1993, No. 10, pp. 36-37.

- $\quad$ 1993h, Editors. GIS in België: verdeeldheid troef. Vi Matrix, Vol. 1993, No. 12, p. 49.

- 1993i, Peter Mom. Tien profs tekenen bestek voor een Vlaams 'GIS-huis. Vi Matrix, Vol. 1993, No. 10, pp. 34-35.

- $\quad$ 1994a, Peter Mom. Belgacom talmt met participatie Cardib. Vi Matrix, Vol. 1994, No. 03, p. 42.

- $1994 b$, Peter Mom. Cardib valt van de ene verbazing in de andere. Vi Matrix, Vol. 1994, No. 12, pp. 38-39.

- 1994c, Peter Mom. Slechten GIS-barrière plaatst gemeenten voor nieuw obstakel. Vi Matrix, Vol. 1994, No. 03, pp. 20-23.

- $\quad$ 1994d, Peter Mom. Weg vrij voor GIS-Vlaanderen. Vi Matrix, Vol. 1994, No. 06, pp. 44-44.

- 1994e, Peter Mom. Vlaamse GIS-werkgroep vergadert hevig voort. Vi Matrix, Vol. 1994, No. 10, pp. 2-3.

- 1994f, Peter Mom. Optimisme over GIS Vlaanderen moet men soms van verre zoeken. Vi Matrix, Vol. 1994, No. 10, pp. 6-7.

- $\quad$ 1995a, J.B. van der Veen, H.T. Uitermark. Naar een objectgerichte GBKN?! Van basiskaart tot basisbestand via het objectbegrip. Geodesia, Vol. 1995, No. 02, pp. 83-88.

- 1995b, C.H.J. Lemmen. Topologie en unike objectidentificatie. Enige aspecten bij het uitwisselen van ruimtelijke gegevens. Geodesia, Vol. 1995, No. 05, pp. 231-235.

- 1995c, Peter Mom. GIS-Vlaanderen krijgt stilaan de allure van een fata morgana. Vi Matrix, Vol. 1995, No. 01, pp. 6-9.

- $\quad$ 1995d, Peter Mom. Regeringsbesluit GIS-Vlaanderen. Vi Matrix, Vol. 1995, No. 06, p. 47.

- 1996a, Berry van Osch. Van de redactie: De objectgerichte GBKN: wanneer komt er schot in?. Geodesia, Vol. 1996, No. 04, p. 138.

- 1996b, Theo Scheele. Themadag Objectgerichte GBKN in Zeeland. Geodesia, Vol. 1996, No. 12, pp. 553-554.

- 1997a, Ad van der Meer. Van de redactie: Objectgerichte GBKN als religieus dispuut. Geodesia, Vol. 1997, No. 04, p. 154.

- $1997 b$, Jaap van der Veen. Objectgerichtheid en de GBKN. Een manier om tot standaardisatie te komen. Geodesia, Vol. 1997, No. 05, pp. 227-228.

- $\quad 1997 c$, Berry van Osch. Zijn we wel klaar voor een Objectgerichte GBKN?. Geodesia, Vol. 1997, No. 07, p. 298.

- 1997d, René van der Schans. We zijn niet klaar voor een objectgerichte GBKN. Een reactie op Berry van Osch' redactionele commentaar. Geodesia, Vol. 1997, No. 09, p. 397.

- $\quad$ 1997e, Peter Mom. Cardib onvermoeid optimistisch over Grootschalige BasisKaart Vlaanderen. Vi Matrix, Vol. 1997, No. 02, pp. 33-35.

- 1997f, Peter Mom. Interelectra gaat nu met 'Cardib-kaart' eigen weg. Vi Matrix, Vol. 1997, No. 09, pp. 40-42.

- 1997g, Peter Mom. Cardib en OC optimistisch over één grootschalige basiskaart. Vi Matrix, Vol. 1997, No. 12, p. 43. 
- 1998, LSV-GBKN. Objectgerichte GBKN voorlopig geen haalbare kaart. Geodesia, Vol. 1998, No. 01 , p. 42.

- 1999a, Landelijk Samenwerkingsverband GBKN. GBKN-vervaardiging bijna gereed. Geodesia, Vol. 1999, No. 06, p. 297.

- 1999b, J.C. Meerkerk, J.B. van der Veen. De GBKN, klaar voor de 21ste eeuw!?. Geodesia, Vol. 1999, No. 04, pp. 163-169.

- $\quad$ 1999c, Peter Mom. OC start scanproject. Vi Matrix, Vol. 1999, No. 02, p. 36.

- 1999d, Peter Mom. Grootschalig Referentie Bestand voor Vlaanderen haalbare kaart. Vi Matrix, Vol. 1999, No. 12, pp. 38-40.

- $\quad 1999$ e, Peter Gorlé. Samenwerking GIS-Vlaanderen krijgt decretale basis. Vi Matrix, Vol. 1999, No. 09, pp. 34-37.

- 2000a, J. Polman. Hink, Stap, Sprong. De geschiedenis van het ontstaan van de GBKN. Geodesia, Vol. 2000, No. 07, pp. 319-326.

- 2000b, L.M. Murre. GBKN anno 2000. De stand van zaken en het perspectief voor de toekomst. Geodesia, Vol. 2000, No. 07, pp. 327-332.

- 2000c, Editors. GIS bij wet geregeld. Vi Matrix, Vol. 2000, No. 09, p. 41.

- 2001a, L.M. Murre. Laatste GBKN in Hardinxveld/Giessendam opgeleverd. Geodesia, Vol. 2001, No. 02, p. 83.

- 2001b, J.C. Meerkerk, J.W.F.M. van Grunsven. GBKN, van aanbod naar vraaggericht. Geodesia, Vol. 2001, No. 03, pp. 117-121.

- 2001c, LSV-GBKN. Berichten uit de Stuurgroep GBKN. Geodesia, Vol. 2001, No. 12, p. 600.

- 2001d, Peter Mom. GRB Vlaanderen staat op de rails. Vi Matrix, Vol. 2001, No. 12, pp. 28-30.

- 2002a, Ad van der Meer. De GBKN een authentieke registratie? Geodesia, Vol. 2002, No. 06, p. 235.

- 2002b, Ad van der Meer. De GBKN-kip en het AR-ei. Geodesia, Vol. 2002, No. 09, p. 327.

- 2002c, N.J.M van Eekelen, E.J.M. Weesie. Instrumenten voor een uniforme GBKN. Geodesia, Vol. 2002, No. 03, pp. 108-110.

- 2002d, Adri den Boer. Geo-informatiebeleid in Tweede Kamer. Geodesia, Vol. 2002, No. 09, pp. 322-326.

- 2002e, Leen Murre. Topografie en gemeenten. Geodesia, Vol. 2002, No. 10, p. 387.

- 2002f, Peter Mom. Londerzeel prijst de dag dat GRB wordt opgeleverd. Vi Matrix, Vol. 2002, No. 06, pp. 30-31.

- 2003a, H. Schallenberg. De grootschalige basiskaart een gemeentelijke zorg. Geodesia, Vol. 2003, No. 01, pp. 4-9.

- 2003b, L.M. Murre. Nieuwe Stichting LSV GBKN van start. Geodesia, Vol. 2003, No. 09, pp. 342-345.

- 2003c, Adri den Boer. Eindrapportage Stroomlijning Basisgegevens. Geodesia, Vol. 2003, No. 05, pp. 210-212.

- 2003d, E. Scheltes, L.A. Smit, Ad van der Meer, Jan de Kruif. Gemeenten verantwoordelijk voor topografie'. Geodesia, Vol. 2003, No. 02, pp. 82-85.

- 2003e, L.M. Murre. Kunnen 'gemeenten verantwoordelijk zijn voor topografie'?. Geodesia, Vol. 2003, No. 04, p. 179.

- 2003f, E. Dolle. RSV en TPG sluiten aan. Geodesia, Vol. 2003, No. 11, p. 457.

- 2004, Peter Mom. GRB-primeur voor Geetbets. Vi Matrix, Vol. 2004, No. 11, pp. 47-48.

- 2005, Redactie. Minister Kris Peeters volgt realisatie van geo-basisbestanden met argusogen. Vi Matrix, Vol. 2005, No. 12, pp. 44-47.

- 2006a, Adri den Boer. Themabijeenkomst basisregistraties in trek. Geo-info, Vol. 2006, No. 07, pp. 314-316. 
- 2006b, L.M. Murre. Wordt de GBKN een basisregistratie?. Geo-info, Vol. 2006, No. 02, pp. 66-68.

- 2006c, Koen Vervloessem. Iedereen een gelijke manier van aanmeten en alle objecten in de juiste layer. Geoplatform, Vol. 2006, No. 09, pp. 6-9.

- 2006d, Peter van Es. GIS Vlaanderen: verleden, heden en toekomst. Geoplatform, Vol. 2006, No. 09, pp. 10-15.

- 2009a, Adri den Boer, Martin Peersmann. Martin Peersmann: 11 maanden 'mister GBKN2BGT'. Geo-info, Vol. 2009, No. 10, pp. 4-6.

- 2009c, Nico vande Kerkhof. Vlaanderen moet leren omgaan met een gefaseerde GRB-realisatie. Geoplatform, Vol. 2009, No. 09, pp. 14-19.

- 2009b, Ronald Bokhove. Gemeenten kleuren de BGT in, maar hoe?. Geo-info, Vol. 2009, No. 11, pp. 30-32.

- 2010, Adri den Boer, Ruud van Rossem. Ruud van Rossem: nu mister BGT. Geo-info, Vol. 2010, No. 01, pp. 22-24.

- 2011, Adri den Boer. Bronhoudersoverleg BGT op naar uniformering. Geo-info, Vol. 2011, No. 07, pp. 21-22.

- 2012a, Ruud van Rossem. De BGT: van denken naar doen. Geo-info, Vol. 2012, No. 06, pp. 4-8.

- 2012b, Bart Maessen. Landelijke voorziening BGT. Geo-info, Vol. 2012, No. 06, pp. 22-24.

- 2012c, Ernst Koperdraat. Nut en noodzaak van een samenwerkingsverband van bronhouders. Geo-info, Vol. 2012, No. 06, pp. 26-29.

- 2012d, Martin Peersmann, Sieb Dijkstra. Van GBKN naar BGT in historisch perspectief. Geo-info, Vol. 2012, No. 6, pp. 38-42.

- 2013, Editors. Wet BGT door de Eerste Kamer. Geo-info, Vol. 2013, No. 08, p. 44.

- 2014, BGTweb. Valkenswaard als eerste helemaal in de BGT!. Geo-info, Vol. 2014, No. 06, p. 15.

- 2016, Roelof Keppel. Verslag FLAGIS-bijeenkomst 8 december 2015 te Lier (B). Geo-info, Vol. 2016, No. 01, p. 34.

- 2017a, Roelof Keppel; Astrid van den Hoek, Nienke Zeijlemaker. Grip op data: de puzzel van Rijkswaterstaat. Geo-info, Vol. 2017, No. 03, pp. 24-27.

- 2017b, Marcel Rietdijk; Gerlof de haan; Sandra Leijten. Met de BGT op tijdreis door de openbare ruimte. Geo-info, Vol. 2017, No. 03, pp. 30-33.

\section{References}

1. Macharis, C.; Crompvoets, J. A stakeholder-based assessment framework applied to evaluate development scenarios for the spatial data infrastructure for flanders. Comput. Environ. Urban. Syst. 2014, 46, 45-56. [CrossRef]

2. Vancauwenberghe, G. Coordination within Spatial Data Infrastructures: An Analysis of Exchange and Use of Geographical Information in Flanders; KU Leuven: Leuven, Belgium, 2013.

3. Bregt, A.K.; Crompvoets, J.W.H.C. Geo-informatie in de netwerksamenleving, een tweeluik. Vi Matrix 2000, $55,16-19$.

4. Bregt, A.K. Value added services en de nationale geo-informatie infrastructuur. In Proceedings of the Promoting value-added GI services, Den Haag, The Netherlands, 27 January 2006; pp. 77-81.

5. Robichau, R.W. The mosaic of governance: Creating a picture with defintions, theories, and debates. Policy Stud. J. 2011, 39, 113-131. [CrossRef]

6. Pollitt, C.; Bouckaert, G. Public Management Reform. A Comparative Analysis: New Public Management, Governance, and the Neo-Weberian State; Oxford University Press: New York, NY, USA, 2011.

7. Vandenbroucke, D.; Crompvoets, J.; Vancauwenberghe, G.; Dessers, E.; Van Orshoven, J. A network perspective on spatial data infrastructures: Application to the sub-national sdi of flanders (Belgium). Trans. GIS 2009, 13, 105-122. [CrossRef]

8. Hendriks, P.H.J.; Dessers, E.; van Hootegem, G. Reconsidering the definition of a spatial data infrastructure. Int. J. Geogr. Inf. Sci. 2012, 26, 1479-1494. [CrossRef] 
9. Mörth, U. The market turn in eu governance-The emergence of public-private collaboration. Gov. Int. J. Policy Adm. Inst. 2009, 22, 99-120. [CrossRef]

10. Rijke, J.; Brown, R.; Zevenbergen, C.; Ashley, R.; Farelly, M.; Morison, P.; van Herk, S. Fit-for-purpose governance: A framework to make adaptive governance operational. Environ. Sci. Policy 2012, 22, $73-84$. [CrossRef]

11. Fukuyama, F. What is governance? Governance 2013, 26, 347-368. [CrossRef]

12. Coetzee, S.; Wolff-Piggott, B. A review of sdi literature: Searching for signs of inverse infrastructures. In Cartography-Maps Connecting the World; Sluter, C.R., Cruz, C.B.M., Menezes, P.M.L., Eds.; Springer International Publishing: Cham, Switzerland, 2015; pp. 113-127.

13. Kooiman, J. Governing as Governance; SAGE: London, UK, 2003.

14. Rajabifard, A.; Feeney, M.-E.F.; Williamson, I.P. Future directions for sdi development. Int. J. Appl. Earth Obs. Geoinf. 2002, 4, 11-22. [CrossRef]

15. Grus, L.; Crompvoets, J.; Bregt, A.K. Spatial data infrastructures as complex adaptive systems. Int. J. Geogr. Inf. Sci. 2010, 24, 439-463. [CrossRef]

16. Verhoest, K.; Bouckaert, G.; Peters, B.G. Janus-faced reorganization: Specialization and coordination in four oecd countries in the period 1980-2005. Int. Rev. Adm. Sci. 2007, 73, 325-348. [CrossRef]

17. Hood, C. The "new public management" in the 1980s: Variations on a theme. Account. Organ. Soc. 1995, 20, 93-109. [CrossRef]

18. The White House. Coordinating geographic data acquisition and access: The national spatial data infrastructure. In Executive Order 12906; Federal Register: Washington, DC, USA, 1994.

19. Masser, I.A.N. All shapes and sizes: The first generation of national spatial data infrastructures. Int. J. Geogr. Inf. Sci. 1999, 13, 67-84. [CrossRef]

20. Gore, A. Creating a Government that Works Better \& Costs Less; Report of the National Performance Review; Status Report; US Government Printing Office: Washington, DC, USA, 1994.

21. Rajabifard, A.; Feeney, M.E.; Williamson, I.; Masser, I. National sdi initiatives. In Developing Spatial Data Infrastructures: From Concept to Reality; Williamson, I., Rajabifard, A., Feeney, M.-E.F., Eds.; Taylor \& Francis: London, UK, 2003; pp. 99-114.

22. Crompvoets, J.; Bregt, A.; Rajabifard, A.; Williamson, I. Assessing the worldwide developments of national spatial data clearinghouses. Int. J. Geogr. Inf. Sci. 2004, 18, 665-689. [CrossRef]

23. Osborne, S.P. The New Public Governance: Emerging Perspectives on the Theory and Practice of Public Governance; Routledge: Abingdon-on-Thames, UK, 2010.

24. Worthy, B. More open but not more trusted? The effect of the freedom of information act 2000 on the united kingdom central government. Governance 2010, 23, 561-582.

25. European Parliament. Directive 2003/98/ec of the European Parliament and of the Council of 17 November 2003 on the Re-Use of Public Sector Information; European Union: Brussels, Belgium, 2003.

26. Geographic Information Panel. Place Matters: The Location Strategy for Het United Kingdom; Communities and Local Government: London, UK, 2008.

27. Hansen, H.S.; Hvingel, L.; Schrøder, L. Open government data-A key element in the digital society. In Proceedings of the Second Joint International Conference on Electronic Government and the Information Systems Perspective, and Electronic Democracy, Prague, Czech Republic, 26-28 August 2013; pp. 167-180.

28. Bregt, A.K.; Castelein, W.T.; Grus, L.; Eertink, D. De Effecten van een Open Basisregistratie Topografie (Brt); Wageningen University: Wageningen, The Netherlands, 2013.

29. Welle Donker, F. Public sector geo web services: Which business model will pay for a free lunch? In Sdi Convergence. Research, Emerging Trends, and Critical Assessment; Van Loenen, B., Besemer, J.W.J., Zevenbergen, J.A., Eds.; Optima Grafische Communicatie: Delft, The Netherlands, 2009; pp. 35-50.

30. Maguire, D.J.; Longley, P.A. The emergence of geoportals and their role in spatial data infrastructures. Comput. Environ. Urban Syst. 2005, 29, 3-14. [CrossRef]

31. Koerten, H. Taming Technology. The Narrative Anchor Reconciling Time, Territory and Technology in Geoinformation Infrastructures; Delft University of Technology: Amsterdam, The Netherlands, 2011.

32. Sanz, E. Open governments and their cultural transitions. In Open Government: Opportunities and Challenges for Public Governance; Gascó-Hernández, M., Ed.; Springer: New York, NY, USA, 2014; pp. 1-15.

33. Lance, K.T.; Georgiadou, Y.; Bregt, A.K. Cross-agency coordination in the shadow of hierarchy: 'Joining up' government geospatial information systems. Int. J. Geogr. Inf. Sci. 2009, 23, 249-269. [CrossRef] 
34. Bowen, G.A. Document analysis as a qualitative research method. Qual. Res. J. 2009, 9, 27-40. [CrossRef]

35. Bryman, A. Social Research Methods, 4th ed.; Oxford University Press: Oxford, UK, 2012.

36. Scott, J. A Matter of Record; Polity Press: Cambridge, UK, 1990.

37. Ministerie van Infrastructuur en Milieu. Monitorrapportage Juli 2017: Bgt Voortgang Transitie; Ministerie van Infrastructuur en Milieu: Den Haag, The Netherlands, 2017.

38. Vlaamse Raad. Handelingen 7-8-9-10-11, Vergaderingen van November 1992; Vlaamse Raad: Brussels, Belgium, 1992; pp. 237-254.

39. Kok, B.; van Loenen, B. How to assess the success of national spatial data infrastructures? Comput. Environ. Urban Syst. 2005, 29, 699-717. [CrossRef]

40. Minkov, M.; Hofstede, G. Clustering of 316 european regions on measures of values. Cross-Cult. Res. 2014, 48, 144-176. [CrossRef]

41. Oikonomou, I. The 'nationalisation' of the galileo programme. In Theorizing European Space Policy; Hoerber, T.C., Sigalas, E., Eds.; Lexington Books: Lanham, MD, USA, 2016; pp. 141-158.

42. Publieke Dienstverlening op de Kaart (PDOK). Available online: www.pdok.nl (accessed on 19 July 2017).

43. Jessop, B. Governance and meta-governance: On reflexivity, requisite variety and requisite irony. In Governance, as Social and Political Communication; Manchester University Press: Manchester, UK, 2003; pp. 101-116.

44. Dietz, T.; Ostrom, E.; Stern, P.C. The struggle to govern the commons. Science 2003, 302, 1907-1912. [CrossRef] [PubMed]

45. Edelenbos, J.; Bregt, A.; Broesie, R.; Dammers, E.; Meyer, H.; Neumann, D.; Warmerdam, M. An action perspective fot the delta. In New Perspectives on Urbanizing Deltas; Meyer, H., Bregt, A., Dammers, E., Edelenbos, J., Eds.; MUST Publishers: Amersfoort, The Netherlands, 2015; pp. 173-187.

(C) 2017 by the authors. Licensee MDPI, Basel, Switzerland. This article is an open access article distributed under the terms and conditions of the Creative Commons Attribution (CC BY) license (http://creativecommons.org/licenses/by/4.0/). 